\title{
Konflik Internasional Abad ke-21? Benturan Antarnegara Demokrasi dan Masa Depan Politik Dunia
}

\section{Mohamad Rosyidin}

$\begin{array}{ll}\text { Judul } & : \text { The Triumph of Democracy and the Eclipse of the West } \\ \text { Penulis } & : \text { Ewan Harrison and Sara McLaughlin Mitchell } \\ \text { Penerbit } & : \text { Palgrave Macmillan } \\ \text { Cetakan } & : \text { I }(2014) \\ \text { Tebal } & : 264+\text { xviii halaman } \\ \text { ISBN } & : 978-1-137-35386-3\end{array}$

\begin{abstract}
'The clash of civilizations' of Samuel Huntington and 'the end of history' of Francis Fukuyama are two grand theories that have been widely accepted as the most dominant narratives in post-Cold War international relations. Unfortunately, there have been little theoretical developments in today's world to predict the future of international conflict. The theory assumed that the future international conflict will not occur between democracies and non-democracies as Democratic Peace Theory proposed, but between established democracies and emerging democracies. The established democracies reluctant to share their power with the emerging democracies on how to manage global order. This reluctancy will lead to political frictions and conflicts among them. In spite of its theoretical breakthrough, this theory suffers of logical inconsistency since it does not distinguish between emerging democracies and emerging powers. Instead of conflict among democracies, this article argues that international conflicts in the $21^{\text {st }}$ century will be dominated by asimetrical conflict between nation-states and radical movements, conflicts due to information openess, and conflict over natural resources.
\end{abstract}

\section{Keywords:}

international conflict; the clash of democratization theory.

\begin{abstract}
Abstrak
Tesis 'benturan antar peradaban' dari Samuel Huntington dan 'akhir sejarah' dari Francis Fukuyama merupakan dua teori besar yang dipandang luas sebagai narasi paling dominan pada pasca Perang Dingin. Sayangnya, sedikit sekali prestasi teoretis semacam itu di era sekarang untuk memprediksi masa depan konflik internasional. Teori 'benturan antar demokrasi' berasumsi bahwa konflik internasional yang akan datang bukan konflik antara negara demokrasi dan non-demokrasi sebagaimana proposisi Teori Perdamaian Demokratis, melainkan antara negara demokrasi mapan dan negara demokrasi baru. Negara demokrasi mapan enggan berbagi kekuasaan dengan negara demokrasi baru dalam mengelola tatanan global. Keengganan tersebut akan memicu gesekan dan konflik politik di antara mereka. Meskipun muncul dengan terobosan teoretis, teori ini mengandung inkonsistensi karena tidak membedakan antara negara demokrasi
\end{abstract}

\footnotetext{
- Dosen Program Studi Ilmu Hubungan Internasional FISIP Universitas Diponegoro.
}

Email: mohamad.rosyidin@gmail.com 
baru dan kekuatan yang sedang bangkit. Tulisan ini berpendapat bahwa alih-alih konflik antar negara demokrasi, skenario konflik masa depan akan lebih banyak berkutat pada tiga bentuk: konflik asimetris antara negara dan kelompok radikal, konflik akibat keterbukaan informasi, dan konflik perebutan sumberdaya alam.

\section{Kata Kunci:}

konflik internasional; teori benturan antar negara demokrasi.

Dua tokoh terkemuka realisme politik internasional, John Mearsheimer dan Stephen Walt (2013), menulis bahwa penelitian yang hanya sekedar menguji hipotesis dengan data empiris mencerminkan prospek kemunduran dalam perkembangan studi Hubungan Internasional (HI). Menurut mereka, kebanyakan karya dalam bidang studi HI saat ini bertujuan bukan untuk menciptakan teori, melainkan sekedar menguji teori dengan menitikberatkan pada kekuatan data. Pendapat itu sesuai dengan kenyataan sebab sangat jarang ilmuwan HI membuat terobosan besar sebagaimana yang telah dilakukan oleh para teoretis seperti Kenneth Waltz, Alexander Wendt, Samuel Huntington, dan Francis Fukuyama. Para pemikir ini tidak saja mengguncang dunia keilmuan karena keaslian gagasan mereka, tetapi juga mampu mempengaruhi dunia hingga beberapa dekade. Jika dahulu para ilmuwan cukup produktif dalam menghasilkan sebuah teori umum (grand theory) yang memiliki kemampuan prediktif yang sangat akurat tentang masa depan dunia, kini prestasi semacam itu semakin langka.

Romantisme akan kemunculan gagasan besar yang menawarkan gambaran masa depan dunia direspon dengan sangat baik oleh dua pengarang buku ini. Buku ini berupaya menawarkan cara pandang baru terhadap lanskap politik internasional abad ke-21. Mereka terobsesi dengan gagasan Huntington tentang "benturan antarperadaban" dan ide Fukuyama mengenai "berakhirnya sejarah." Gagasan kedua ilmuwan Amerika itu dapat memproyeksikan dengan sangat akurat pola dan kecenderungan politik internasional pasca runtuhnya Uni Soviet. Tragedi 11 September 2001 yang menyulut pecahnya Perang Afganistan dan Perang Irak disebutsebut sebagai puncak keakuratan prediksi Huntington. Sementara itu, tren demokratisasi yang melanda banyak negara mengonfirmasi teori Fukuyama. Kedua penulis pun mengakui bahwa karya mereka merupakan sintesis antara gagasan Fukuyama dan Huntington (hlm. 12). Dari Fukuyama, buku ini setuju dengan tesis bahwa demokrasi akan tetap menjadi ideologi favorit negara-negara di dunia, sedangkan dari Huntington, buku ini sepakat bahwa masa depan politik internasional akan tetap diwarnai oleh konflik.

Tulisan ini adalah ulasan terhadap buku Harrison dan Mitchell, yang akan dibagi dalam tiga bagian. Bagian pertama tulisan mengulas teori ketidakdamaian demokrasi yang menjadi inti argumen buku ini. Teori ini menyangkal argumen teori perdamaian demokratis yang beranggapan bahwa sesama negara demokrasi tidak akan berkonflik satu sama lain. Kontras dengan klaim tersebut, buku ini berpendapat bahwa konflik antarnegara demokrasi disebabkan oleh perbedaan kepentingan antara negara demokrasi baru dan negara demokrasi yang sudah mapan. Bagian kedua tulisan memberikan komentar terkait argumen utama buku ini. Beberapa kelemahan buku ini antara lain bahwa bangunan argumentasinya mengandung kontradiksi internal, kekeliruan konseptual dalam memahaminegara demokrasi yang baru muncul (emerging democracies) dan kekuatan baru yang sedang tumbuh (emerging powers), pengabaian prediksi sebelumnya, dan ketidakjelasan dalam memaknai konflik dan 
perang. Bagian ketiga tulisan ini memberikan pandangan alternatif mengenai wajah konflik internasional abad ke-21. Setidaknya terdapat tiga bentuk konflik internasional di masa yang akan datang, yakni konflik asimetris, konflik teknologi, dan konflik perebutan sumberdaya alam.

\section{Teori Ke(tidak)damaian Demokrasi}

Gelombang demokratisasi yang melanda negara-negara Arab di Timur Tengah dan Afrika Utara - dikenal juga sebagai Arab Spring- memperkuat tesis Fukuyama tentang kemenangan ide Barat. ${ }^{1}$ Fenomena itu menepis pesimisme Huntington (1991) yang mengatakan bahwa selain Konfusianisme, Islam merupakan budaya yang menjadi pengalang terbesar bagi demokratisasi. Tesis Huntington meleset dalam mengaitkan antara faktor budaya dan prospek demokratisasi. Tumbangnya rezimrezim otokratik Timur Tengah lebih sesuai dengan optimisme Larry Diamond (1997: 52) yang mengatakan bahwa "Di negara-negara Islam Timur Tengah juga, [perkembangan] demokrasi tampaknya masuk akal di masa yang akan datang." Runtuhnya pemerintahan otokratik Timur Tengah membuktikan tidak adanya alternatif ideologi politik yang lebih baik selain demokrasi.

Pertanyaannya kemudian adalah bagaimana dampak perubahan politik itu terhadap hubungan internasional? Buku ini berangkat dengan asumsi bahwa Arab Spring memunculkan paradoks yang bertolak belakang dengan pandangan kaum liberaldemokratik. Menurut pandangan kaum liberal-demokratik, semakin demokratis sebuah negara, semakin kecil kemungkinan negara tersebut berkonflik dengan negara yang

\footnotetext{
Istilah 'Barat' di sini merujuk pada kawasan Eropa Barat dan Amerika Utara. Dalam sejarah pemikiran umat manusia, ide-ide Barat berakar dari peradaban Yunani dan Romawi yang menjadi cikal-bakal tatanan masyarakat Eropa modern, seperti ide tentang demokrasi dan liberalisme.
}

juga demokratis. Dalam tradisi teoretis HI, pandangan ini dikenal dengan teori perdamaian demokratis (democratic peace theory) yang berasumsi bahwa sesama negara demokrasi tidak akan berperang satu sama lain. Konflik hanya terjadi antara negara demokrasi melawan negara non-demokrasi. Pandangan ini ditolak oleh Harrison dan Mitchell, yang menulis bahwa konflik masa depan bukan berupa konflik antara negara demokrasi melawan negara non-demokrasi, juga bukan "benturan peradaban," tetapi "benturan demokratisasi" (hlm. x). "Benturan demokratisasi" adalah konflik antarnegara demokrasi, khususnya antara negara demokrasi Barat yang sudah mapan (established democracies) dan negara demokrasi baru yang sedang berkembang (emerging democracies). Implikasinya, sekalipun demokrasi telah menjadi ideologi dominan umat manusia, politik dunia tetap akan diliputi oleh pesimisme mengenai prospek perdamaian antarnegara.

Basis argumentasi konflik antara established democracies dan emerging democracies berakar dari kondisi demokrasi di kedua kubu. Established democracies adalah negara-negara Barat yang kondisi demokrasinya sudah terkonsolidasi dengan baik. Sementara itu, emerging democracies adalah negara-negara demokrasi 'Dunia Ketiga' yang kurang terkonsolidasi sehingga rentan mengalami kemunduran (hlm. 103). Perbedaan ini menimbulkan ketidakpercayaan di kalangan negara demokrasi mapan terhadap negara demokrasi baru itu. Negara-negara Barat menghadapi dilema mengenai format kerja sama yang akan mereka bangun dengan negara demokrasi baru. Di satu sisi, mereka bersuka cita menyambut masuknya negaranegara demokrasi baru ke dalam "komunitas demokrasi,"karena itu artinya menambah jumlah teman yang berpeluang menjadi sekutu atau mitra kerja sama. Namun di sisi lain, negara-negara Barat cenderung enggan berbagi tanggung jawab dan kekuasaan (power sharing) terkait tata kelola global (global governance) 
dengan "kawan baru" mereka. Cepat atau lambat, negara demokrasi baru akan menuntut peran yang lebih besar dalam berbagai isu internasional. Itu artinya, mereka menghendaki agar Barat bersedia berbagi tempat dengan mereka. Namun, bagi Barat, mengakomodasi permintaan dari negara demokrasi baru untuk mendapatkan akses terhadap kekuasaan dan tanggung jawab internasional akan sangat menyakitkan (hlm. 157). Aspirasi negara demokrasi baru akan status dan peran mereka di dunia internasional, ditambah dengan resistensi Barat untuk melibatkan mereka, akan berujung pada konflik yang mengganggu stabilitas sistem internasional.

Jangan dibayangkan konflik antara Barat dan negara demokrasi baru itu berupa konflik bersenjata atau perang. Konflik yang akan terjadi lebih bersifat politis ketimbang militer (hlm. 162). Konflik dua kubu negara demokrasi yang berbeda pengalaman sejarah itu terfokus pada masalah tata kelola global. Kemunculan negara-negara demokrasi dari Dunia Ketiga membawa aspirasi untuk merestorasi tatanan global yang telah lama didominasi oleh Barat, misalnya reformasi institusi keuangan internasional seperti IMF dan Bank Dunia yang selama ini hanya menjadi alat kepentingan Barat. Kepemimpinan organisasi-organisasi ini tidak bisa lagi menjadi hak prerogatif Amerika Serikat (AS) dan Eropa (hlm. 165). Munculnya Brazil dan India sebagai kekuatan besar dari Dunia Ketiga juga turut membawa aspirasi untuk mereformasi Dewan Keamanan Perserikatan Bangsa-Bangsa (DK PBB). Isu lain seperti liberalisasi perdagangan dan lingkungan juga mencerminkan bagaimana benturan itu terjadi. Kebijakan Barat menutup pintu impor produk-produk tekstil dan pertanian dari negara sedang berkembang serta keengganan untuk meratifikasi Protokol Kyoto merupakan simpul konflik kedua kubu. Kesimpulannya, konflik itu terjadi karena masalah psikologis semata, yakni kecenderungan Barat (The West) untuk mempertahankan status quo di saat negara-negara di belahan dunia lain (The Rest) terus mengalami kemajuan dalam mengadopsi nilai-nilai Barat.

Untuk menghindari benturan, solusinya adalah mengupayakan "proses sosialisasi timbal-balik" (hlm. 157) antara Barat dan negara demokrasi baru. Barat harus bersedia berbagi kekuasaan dan wewenang dengan negara demokrasi baru, sementara yang terakhir ini harus serius untuk meninggalkan identitasnya sebagai negara sedang berkembang. Sosialisasi harus bersifat dua arah, yaitu negara Barat tidak boleh secara sepihak mengajari negara non-Barat norma yang mereka anut, tetapi juga mau mendengarkan dan mengapresiasi aspirasi negara non-Barat (Xiaoyu, 2012). Kishore Mahbubani (2011: 257) sudah mengajukan rekomendasi semacam ini: "Sudah tiba waktunya bagi Barat untuk mempertimbangkan kemungkinan bahwa bangsa lain dan komunitas lain juga sekompeten seperti Barat, jika tidak mau dikatakan lebih kompeten, dalam menjawab tantangan global dan regional." Jika Barat selalu mendorong negara lain untuk menjadi demokratis, ia harus berkomitmen untuk mengikutsertakan mereka dalam tata kelola global. Sayangnya, Barat masih belum mau mengakui kompetensi kekuatan-kekuatan lain di luar dirinya. Barat masih belum mampu melepaskan diri dari pemikiran kolot bahwa mereka adalah puncak peradaban universal dan ditakdirkan sebagai penguasa dunia.

Ironisnya, resistensi tidak hanya menjangkiti negara-negara Barat saja, melainkan juga negaranegara demokrasi baru. Misalnya India, tidak mau melepaskan identitasnya sebagai negara Dunia Ketiga. Narlikar (2006: 76) mengatakan bahwa India "tidak sepenuhnya meninggalkan diplomasi pro-Dunia Ketiga-nya, retorika peradabannya atau [memilih] strategi distributif yang mendukung negara-negara maju." Latar belakang sejarah India sebagai negara bekas penjajahan membuat ia memiliki ikatan emosional dengan sesama negara Dunia Ketiga. 
Terlebih lagi, masuknya India dalam forum BRICS (Brazil, Rusia, India, China, dan South Africa) menjadikan kebijakan luar negerinya lebih condong pada kepentingan negara-negara sedang berkembang. Meskipun India menjalin hubungan diplomatik yang sangat erat dengan Barat (Amerika Serikat), tetapi India mampu memainkan identitas yang berbeda untuk menjaga keseimbangan antara Barat dan nonBarat (Rosyidin, 2013). Resistensi India ini bisa menghambat proses sosialisasi timbal-balik karena justu akan menciptakan garis demarkasi identitas antarnegara demokrasi. Meskipun sama-sama menganut demokrasi, bahkan Presiden Barack Obama pernah mengatakan bahwa India dan Amerika Serikat adalah "sekutu alami" (natural ally) karena sama-sama sebagai negara demokrasi terbesar di dunia, namun keengganan India untuk menanggalkan identitasnya sebagai 'aspirator negara sedang berkembang' menciptakan gesekan-gesekan politik antara negara-negara maju dan sedang berkembang.

Berbekal skenario semacam itu, masa depan politik dunia masih akan tetap suram. Kendati semakin banyak negara yang memilih demokrasi sebagai sistem politik yang dapat menjanjikan kemakmuran dan kemajuan, namun dalam praktiknya perdamaian yang dielu-elukan oleh para pendukung teori perdamaian demokratis tidak mudah untuk diwujudkan. Sifat keras kepala Barat sebagai pihak yang merasa berhak mengatur dunia, ditambah dengan tipikal negara-negara demokrasi baru yang cenderung anti status quo, menimbulkan friksi-friksi politik yang tak terhindarkan.

\section{Emerging Democracies atau Emerging Powers?}

Meskipun mencoba merevisi tesis Huntington dan Fukuyama, buku ini mengandung beberapa kelemahan, dengan satu di antaranya cukup fatal. Pertama, buku ini menyampaikan pesan optimisme kepada pembaca, tetapi argumentasi yang dibangun jelas dipengaruhi oleh pesimisme ala Huntington. ${ }^{2}$ Alasannya, tersebar-luasnya demokrasi ke seluruh dunia merupakan pertanda baik bagi masa depan umat manusia. Demokrasi yang mengglobal berarti membuka peluang bagi terciptanya tatanan dunia yang damai, stabil, makmur, penuh kerja sama, dan kebebasan manusia yang tak pernah terjadi sebelumnya (hlm. 20). Pernyataan ini tentu kontradiktif dengan paradigma konfliktual yang dipakai sebagai basis argumentasi buku ini. Jika dunia yang akan datang diwarnai oleh konflik antar sesama negara demokrasi, maka optimisme bahwa demokrasi akan membawa tatanan dunia seperti itu jelas tidak dapat diterima.

Kedua, yang paling fatal, buku ini tidak konsisten dalam memilih variabel dependen untuk membangun teori tentang benturan antarnegara demokrasi. Secara metodologis, buku ini tidak konsisten dalam bangunan teoritisnya; kesahihan internal teori yang dikemukakan dalam buku ini amat lemah. Buku ini ingin menjelaskan konflik antara negara demokrasi Barat dan negara demokrasi baru (emerging democracies), namun dalam perjalanannya buku ini justru mengambil kasus-kasus konflik antara kekuatan Barat dan kekuatan Dunia Ketiga yang sedang mengalami kebangkitan (emerging powers) seperti India, Cina, Rusia, Brazil, dan lain-lain. Negara-negara itu tidak bisa dikategorikan sebagai emerging democracies. Kecuali Cina dan Rusia, kekuatan-kekuatan dunia baru yang sekaligus merupakan negara-negara demokrasi baru, seperti Brazil, Turki, Indonesia, dan India, adalah "global swing states," 3 (Kliman and

2 Pesimisme Huntington berangkat dari paradigma realis yang menekankan pada sifat hubungan internasional yang cenderung konfliktual. Huntington melihat konflik internasional pasca Perang Dingin bukan lagi konflik ideologi, melainkan konflik identitas.

3 Global swing states merujuk pada negara-negara yang mengombinasikan kebijakan pro-negara maju dan pro-negara berkembang. Mereka cenderung 
Fontaine, 2012) yang kendati memiliki pretensi untuk mereformasi tatanan global, namun tidak sampai menimbulkan gejolak internasional yang mengganggu. Sama seperti negaranegara besar lainnya, mereka lebih cenderung pragmatis dengan mengintegrasikan diri dalam tata kelola internasional ketimbang berupaya menciptakan gelombang revolusi untuk mengubahnya (Kahler, 2013: 712). Kontras dengan hal tersebut, buku ini berpandangan bahwa aspirasi global negara-negara itu akan menimbulkan konflik internasional. Alhasil, konflik seperti yang digambarkan dalam buku ini lebih condong pada konflik antara emerging powers melawan established powers, bukan antara emerging democracies dan established democracies.

Secara konseptual, terdapat perbedaan mendasar antara emerging democracies dan emerging powers dalam hal strategi dan prioritas kebijakan luar negeri. Negara demokrasi baru, setidaknya untuk jangka pendek, tidak memprioritaskan kebutuhan untuk berbagi peran dan tanggung jawab internasional bersama dengan negara demokrasi maju. Mereka lebih memusatkan perhatian pada konsolidasi demokrasi di dalam negeri ketimbang berambisi mendapatkan status istimewa di level internasional. Mereka harus memperkuat pondasi domestik sebelum berkiprah di level internasional dan memperkuat struktur ekonomi supaya mampu meningkatkan posisi tawar di hadapan negara lain. Diamond berpendapat bahwa kebanyakan negara demokrasi baru memerlukan reformasi kelembagaan dan memperkuat "demokrasi delegatif" karena masih kuatnya partikularisme, minimnya akuntabilitas, dan korupsi (dalam Diamond et.al, 1997: xviii). Berbeda dengan emerging democracies, negara

mempertahankan tatanan internasional yang sudah ada, meskipun kadangkala masih berkeinginan untuk mereformasinya. Mereka adalah negara-negara yang memiliki kapabilitas ekonomi yang kuat, letak geografis yang strategis, dan mengadopsi sistem demokrasi. emerging powers memiliki kepentingan untuk meningkatkan status dan peranan mereka di level internasional. Mengutip kalimat Voltaire, "kekuatan yang besar mendorong tanggung jawab yang besar" (withgreat power comes great responsibility). Negara emerging powers umumnya memiliki pondasi ekonomi yang kokoh dan militer yang kuat. Mengikuti logika perimbangan kekuatan klasik, tidak boleh ada satu pun negara yang mendominasi sistem internasional. Ketika kekuatan-kekuatan baru itu tumbuh, mereka menghendaki supaya dominasi segera diakhiri. Dalam proses inilah benturan kepentingan antara kekuatan baru dan lama terjadi.

Ketiga, masih berhubungan dengan argumen sebelumnya, gagasan tentang konflik antara Barat dan negara sedang berkembang sebagai bagian dari teori "benturan demokratisasi" tidaklah bersifat prediktif. Konflik seperti itu sudah lama terjadi seiring dengan munculnya kekuatan-kekuatan besar dari negara non-Barat, khususnya Asia. Jim O'Neill pada tahun 2001 sudah memprediksi munculnya kekuatan-kekuatan ekonomi baru yang akan mengubah pola interaksi internasional. Dalam tulisannya, O'Neill (2001: 10) menganjurkan supaya forum-forum pembuat kebijakan dunia perlu ditata kembali; forum G7 secara khusus harus memasukkan kekuatan-kekuatan baru tersebut supaya "pembuatan keputusan global [menjadi] lebih efektif." Munculnya kekuatan-kekuatan baru non-Barat akan mengubah sistem internasional yang tadinya unipolar menjadi multipolar. Seperti dikatakan Andrew Cooper and Alan Alexandroff (2010: 6), “Kunci tatanan [global] abad ke-21 akan ditentukan oleh bagaimana visi kekuatan-kekuatan baru itu terhadap organisasi tata kelola global. [Sedangkan] masalahnya terletak pada upaya kekuatankekuatan lama untuk mempertahankan hak istimewanya." Dengan kata lain, konflik yang digambarkan merupakan konflik antarnegara demokrasi sebenarnya merupakan konflik 
yang muncul sebagai konsekuensi logis dari pergeseran kekuatan global (power shift) yang sudah tampak kecenderungannya pada awal dekade 2000-an.

Keempat, buku ini mendua dalam memprediksi bentuk konflik internasional masa depan. Sebagaimana sudah disampaikan, Harrison dan Mitchell berargumen bahwa bentuk konflik antara Barat dan non-Barat di masa depan adalah konflik politik, bukan militer. Hal ini berarti konflik yang dimaksud hanya sebatas gesekan kepentingan atau perbedaan pendapatyang tidak akan bereskalasi menjadi benturan (clash) dalam pengertian yang sebenarnya. Benturan yang terjadi hanya di tataran ide, bukan fisik. Menurut buku ini, hal itu disebabkan kecenderungan negara demokratis untuk menyelesaikan masalah dengan cara non-kekerasan (hlm. 154). Konsepsi konflik internasional masa depan ini jelas berbeda dengan konsepsi Huntington yang mendefinisikan "benturan" sebagai konflik fisik alias perang. Huntington (1993: 25) menulis bahwa "perbedaan antarperadaban telah menimbulkan konflik yang paling lama dan paling keras [cetak miring dari penulis]." Akibat kesalahan konseptual tentang bentuk konflik masa depan ini, buku ini telah mengaburkan perbedaan antara kondisi perang dan damai. Dalam khasanah pemikiran HI, konflik tanpa melibatkan benturan fisik dapat disebut sebagai kondisi damai. Buku ini terlalu membesar-besarkan persoalan perbedaan pendapat dan kepentingan antara Barat dan non-Barat sebagai sebuah skenario konflik masa depan. Mengingat hubungan internasional tidak mungkin sepenuhnya diliputi kerja sama, konflik-konflik yang disebabkan oleh perbedaan pendapat dan kepentingan antarnegara, sekalipun tanpa melibatkan kekuatan militer, adalah hal yang lumrah.

Di luar hal tersebut, paradigma buku ini yang melihat dunia secara konfliktual sebetulnya bukan barang baru. Skenario semacam itu sudah diajukan oleh beberapa pakar hubungan internasional beberapa tahun lalu. Kupchan dalam bukunya yang berjudul No One's World (2012) menyatakan bahwa abad ke21 bukan milik Amerika Serikat, Eropa, apalagi Cina. Dalam situasi di mana terdapat banyak pusat gravitasi kekuatan dunia, konflik akan semakin banyak bermunculan. Sejalan dengan hal itu, Bremmer (2012) juga menyatakan dengan nada pesimis bahwa kondisi di mana tidak ada kepemimpinan global atau "G-Zero World," kapabilitas negara-negara untuk menjaga perdamaian akan berkurang; mereka akan kesulitan dalam memperluas kerja sama dan akan menciptakan sumber-sumber pertikaian baru.

\section{Memetakan Konflik Internasional di Abad ke-21}

Memprediksi adalah upaya tersulit dalam kegiatan keilmuan. Memprediksi pada dasarnya tidak sama dengan meramal. Bila meramal tidak membutuhkan penalaran, memprediksi mensyaratkan adanya analisis sebagai bahan pertimbangan untuk mengeluarkan dugaan-dugaan tentang apa yang akan terjadi. Memprediksi sama artinya dengan mengajukan hipotesis, berhipotesis juga berarti berteori. Memprediksi adalah kegiatan men-teori-kan masa depan.

Dalam literatur politik internasional, sudah banyak upaya prediksi yang dilakukan para sarjana Barat dalam memetakan masa depan konflik internasional. Salah satu prediksi yang sangat berbobot, namun sekaligus memicu kontroversi besar, adalah teori Huntington tentang "benturan antarperadaban." Prediksi Huntington mampu menjelaskan dengan baik perihal konflik antara perdaban Barat dan non-Barat, khususnya Islam dan Cina. Akan tetapi, analisis itu cenderung sangat simplistis sehingga terkesan mengabaikan dimensidimensi internal dari setiap peradaban. Sebagai contoh, konflik yang terjadi di Timur Tengah dan Afrika kebanyakan bernuansa sektarian 
yang memecah-belah suatu negara ketimbang konflik antarnegara. Bahkan di Cina, konflik kerap terjadi di Xinjiang antara etnis Uighur dan mayoritas Han. Artinya, dunia masih diwarnai oleh "sindrom pasca Perang Dingin," yakni konflik-konflik internal yang berlatarbelakang perbedaan identitas.

Tulisan ini berpendapat bahwa sejak berakhirnya Perang Dingin hingga sepuluh atau dua puluh tahun mendatang, konflik akibat perbedaan identitas masih akan mendominasi wajah politik dunia abad ke-21. Konflik seperti ini lebih berbahaya dibandingkan konflik antarnegara yang relatif lebih mudah dicari penyelesaiannya. Alasannya, konflik identitas bersumber dari nilai-nilai yang diyakini sehingga seringkali konflik tidak lagi rasional. Sebagai contoh, konflik etnis antara Hutu dan Tutsi, Bosnia dan Serbia, dan lain sebagainya membunuh jutaan jiwa, belum lagi dendam yang diwariskan secara turun-temurun solusi berjangka panjang atasnya sulit dicari. Klaim ini tentu saja bukan berarti mengesampingkan konflik antarnegara, namun saat ini konflik akan memiliki bentuk yang lebih kompleks dibandingkan konflik antarnegara klasik di mana satu negara secara frontal menyerang negara lainnya. Agresi Rusia terhadap Ukraina baru-baru ini, misalnya, mencerminkan anakronisme itu. Intervensi militer Rusia di Ukraina dianggap sebagian besar pengamat dan komunitas internasional sebagai "sindrom Perang Dingin" (Slantchev, 2014). Anggapan ini tidak terlalu berlebihan sebab cara-cara konflik antarnegara semacam itu, di mana satu negara melanggar kedaulatan negara lain secara langsung, merupakan karakteristik dari politik internasional era Perang Dingin.

Perang antarnegara seperti invasi AS ke Afganistan dan Irak mungkin akan terjadi lagi dalam waktu dekat. Tetapi, sekali lagi tulisan ini berpendapat bahwa konflik semacam itu lebih dipicu oleh masalah lain yang jauh lebih kompleks ketimbang sekedar mengatakan bahwa faktor utamanya adalah keamanan nasional negara penyerang. Perang sangat mungkin didorong oleh doktrin klasik "just war" yang lebih mempertimbangkan aspekaspek kemanusiaan seperti pelanggaran berat hak asasi manusia (HAM) oleh rezim otoriter. Invasi NATO ke Libya pada 2011 merupakan contoh kasus menarik bagaimana konflik antarnegara berjalin-berkelindan dengan konflik yang terjadi di dalam negara tersebut. Berbeda dengan serangan AS ke Afganistan dan Irak, serangan negara-negara Barat ke Libya dipicu oleh perang saudara antara kelompok pro dan anti-pemerintah. Begitu pula, intervensi militer Perancis ke Mali pada 2013 juga dipicu oleh konflik yang terjadi di dalam negara itu. Jadi, dapat dikatakan bahwa konflik antarnegara sekarang dan di masa depan akan tumpang-tindih dengan konflik internal di salah satu negara yang terlibat.

Masih terkait dengan karakteristik konflik di atas, kondisi keamanan internasional akan diperburuk dengan menguatnya kelompok fanatik yang merongrong kekuasaan negara. Kelompok-kelompok radikal sejak lama menjadi musuh nomor satu bagi seluruh negara di dunia untuk diperangi. Konflik antara aktor negara melawan aktor nonnegara ini dapat disebut sebagai konflik asimetris. Ferguson dan Mansbach (2004: 254) menulis bahwa "Melihat berbagai konflik yang sedang muncul, perang pos-internasional akan mengambil bentuk [perang] asimetri." Konflik asimetris didefinisikan sebagai konflik antara pihak-pihak yang memiliki kesenjangan dalam hal sumberdaya, kekuasaan, dan strategi. Pola konflik semacam ini sebetulnya sudah lama terjadi, tetapi menguat kembali sejak permulaan abad ke-21 ketika negara-negara Barat berperang melawan kelompok-kelompok radikal yang berafiliasi dengan jaringan teroris Al Qaeda.

Perang asimetris cenderung berlangsung lebih lama dibandingkan perang antarnegara konvensional. Bandingkan antara invasi Rusia 
ke Ukraina yang hanya berlangsung sekejap ${ }^{4}$ dengan perang AS melawan gerilyawan di Irak dan Taliban di Afganistan yang berlangsung bertahun-tahun tanpa menemukan titik akhir. Pakar geopolitik George Friedman memprediksi bahwa konflik antara AS melawan kelompok radikal belum menujukkan tanda-tanda akan berakhir dan paling tidak akan berlangsung hingga tahun 2020 (Friedman, 2009: 38). Ketika Presiden George W. Bush (2003) mengklaim dalam pidatonya bahwa "kita telah menang" (mission accomplished), dapat dinilai bahwa kesimpulannya itu terlalu prematur. Faktanya, AS justru semakin dibuat frustrasi dengan semakin meningkatnya perlawanan dari kelompok-kelompok radikal yang muncul secara sporadis di berbagai belahan dunia. Perang asimetris akan menjadi konflik yang tidak berkesudahan.

Di kawasan konflik paling panas, Timur Tengah, dapat dilihat bagaimana perang asimetris berlangsung dengan sengit. Kemunculan kelompok ultra-radikal "Negara Islam" (sering dinamakan ISIS atau the Islamic State in Iraq and Syria) sangat fenomenal: ia dapat menyeret banyak negara - lebih dari 60 negara bergabung dalam koalisi melawan ISIS yang dikomando oleh Amerika Serikat - untuk terlibat langsung di dalam pusaran konflik. Kelompok sempalan Al Qaeda ini menebar teror di dua "negara gagal," yaitu Suriah dan Irak, dan telah memproklamirkan berdirinya "negara Islam," sebuah keputusan berani yang bahkan jauh melampaui Al Qaeda. Sebelum menjelma menjadi perang asimetris, pola konflik yang berkembang mengikuti pola konflik sektarian yang dipicu oleh aksi balas dendam ISIS kepada kelompok minoritas Syiah yang mengontrol Irak. “Balas

\footnotetext{
${ }_{4}$ Meskipun hingga kini konflik kedua negara masih berlangsung, namun eskalasinya relatif menurun jika dibandingkan dengan awal mula agresi yang dilancarkan Rusia pada bulan Maret 2014. Sejak Januari 2015, pertempuran-pertempuran yang terjadi bersifat sporadis yang melibatkan kelompok-kelompok paramiliter antara kedua kubu.
}

dendam," menurut Richard Ned Lebow (2010: 185), “adalah ekspresi kemarahan ... dan semangat" untuk melawan musuh. Konflik horizontal antaraliran keagamaan yang dipadu dengan konflik vertikal melawan negara Irak berkembang seperti bola salju yang akhirnya menyeret keterlibatan negaranegara besar. AS memutuskan melakukan serangan udara yang dibantu oleh Perancis. Sejumlah negara bersepakat untuk membantu menghancurkan ISIS, seperti Turki, Jerman, Australia, Arab Saudi, dan negara-negara sekutu Barat lainnya.

Terlepas dari teori konspirasi yang mengatakan bahwa kekacauan yang diakibatkan oleh kemunculan ISIS adalah bagian dari strategi AS untuk memecah-belah kawasan, ${ }^{5}$ perang asimetris antara sekelompok negara melawan sepasukan kecil kelompok fanatik merupakan fakta yang tidak dapat disangkal. Karena strategi yang dipakai kedua kubu sangat berbeda, dimana negara menggunakan kekuatan militer sedangkan kelompok teroris menggunakan kekuatan teror dan propaganda, maka dapat dipastikan negara sangat sulit memenangkan perang tersebut. Amerika Serikat terbukti sangat kewalahan melawan kelompok militan Taliban di Afganistan dan Pakistan, sekalipun ia mengerahkan alatalat perang berteknologi tinggi seperti drone. Pelajaran ini berpotensi ditiru oleh kelompokkelompok lain dalam meraih tujuan mereka sehingga konflik asimetris akan dapat bertahan cukup lama di waktu yang akan datang.

Selain konflik asimetris yang mengusung visi-visi apokaliptik, konflik masa depan juga

\footnotetext{
Salah satu teori konspirasi itu adalah "Strategi Sarang Lebah" (Hornet's Nest Strategy) yang diungkap oleh mantan pegawai Badan Keamanan Nasional Amerika (NSA) Edward Snowden. Menurut teori ini, kemunculan ISIS tidak dapat dilepaskan dari strategi rahasia antara CIA, MI6, dan Mossad untuk menarik para "ekstrimis"di seluruh dunia ke satu tempat (Timur Tengah) guna mengacaukan stabilitas negara-negara Arab. Teori itu juga mengungkapkan bahwa pemimpin ISIS Abu Bakr Al Baghdadi pernah dilatih oleh Mossad di Yordania (Liveleak, 2014).
} 
sangat dipengaruhi oleh kemajuan teknologi. Dunia digital dewasa ini telah mengalami perkembangan yang sangat luar biasa. Kehidupan manusia di banyak aspek saat ini tidak bisa dilepaskan dari keberadaan Internet. Pesatnya perkembangan teknologi informasi dan komunikasi didasari oleh Hukum Moore yang mengatakan bahwa kecepatan chip komputer pengolah data berlipat setiap 18 bulan atau hanya satu setengah tahun (Schmidt and Cohen, 2013: xiii). Dapat dibayangkan bagaimana teknologi berubah sangat cepat hanya dalam tempo beberapa tahun saja.

Imbas dari kemajuan teknologi dalam bidang hubungan internasional menyentuh sampai pada level kebijakan negara. Menurut Joseph Nye, penguasaan teknologi informasi sangat menentukan pengaruh suatu negara di dunia internasional. Penguasaan teknologi merupakan sumberdaya penting pada abad ke-21 sebagai salah satu instrumen mencapai kepentingan nasional. Nye menyebut sumberdaya ini sebagai cyberpower yang didefinisikan sebagai "kemampuan mencapai keinginan melalui penggunaan sumberdaya informasi yang terkoneksi secara elektronik dalam sebuah ruang cyber" (Nye, 2011: 123). Biasanya, teknologi informasi dapat dimanfaatkan negara sebagai soft power untuk membentuk opini pihak lain, misalnya melalui informasi-informasi yang dipublikasikan di Internet. Namun, teknologi dapat pula berperan sebagai hard power yang mampu memberikan efek mengancam bagi pihak lain, misalnya perang cyber dan penggunaan drone (pesawat tanpa awak berteknologi tinggi).

Insiden Wikileaks dan pembocoran hasil sadapan Badan Keamanan Nasional Amerika (NSA) oleh Edward Snowden merupakan contoh kasus menarik terkait dengan wajah konflik internasional abad ke21. Meskipun teknologi informasi tidak dapat menghapus kedaulatan, ruang cyber tidak mengenal kedaulatan; eksistensinya bahkan dapat melanggar kedaulatan. Ancaman cyber terhadap suatu negara dapat disamakan dengan invasi sehingga dapat dianggap melanggar kedaulatan (Betz and Stevens, 2011: 61). Ketika Wikileaks membocorkan ribuan kawat diplomatik berkategori sangat rahasia (top secret) dan mempublikasikannya ke seluruh dunia melalui Internet, hal ini sama artinya dengan ancaman terhadap keamanan nasional suatu negara. Ancaman ini pada gilirannya dapat memicu kemarahan sehingga berpotensi menimbulkan konflik antarnegara. Meskipun Julian Assange sebagai pendiri Wikileaks dapat dikenai pidana akibat pembocoran informasi, Wikileaks tidak menjadi musuh dalam konflik yang dapat terjadi. Hal yang serupa berlaku dalam kasus pembocoran hasil penyadapan telepon NSA yang dilakukan oleh Snowden. Begitu mengetahui NSA menyadap pembicaraan telepon para pejabat mereka, Jerman dan Brazil marah besar kepada AS dan Indonesia marah kepada Australia. Hubungan Indonesia dan Australia bahkan sempat memburuk akibat kejadian tersebut. Kasus-kasus ini membuktikan bahwa konflik antarnegara di masa yang akan datang tidak hanya dipicu masalah yang terkait dengan kepentingan geopolitik dan geostrategi, tetapi juga diakibatkan maraknya 'kebebasan tanpa batas' ruang cyber yang mengancam keamanan nasional suatu negara.

Bentuk konflik internasional lain di abad ke-21 yang dapat diprediksi adalah konflik yang disebabkan oleh perebutan sumberdaya alam. Sejak ribuan tahun lalu peradaban-peradaban besar dunia saling menaklukkan dan menumpahkan darah satu sama lain demi menguasai sumberdaya alam. Benar kata banyak orang, sejarah selalu berulang. Masa depan umat manusia agaknya akan kembali ke masa lampau di mana negaranegara akan saling berebut sumberdaya alam demi menjaga kelangsungan hidup penduduk mereka. Akses terhadap sumberdaya alam akan menjadi tujuan utama dari strategi keamanan nasional sehingga persaingan dalam 
mendapatkan akses tersebut akan menjadi sumber instabilitas politik internasional (Garrett and Piccini, 2012: 7-8). Bagaimana klaim ini dapat dipercaya? Logikanya cukup sederhana. Jumlah penduduk bumi saat ini lebih dari tujuh milyar jiwa. Menurut data Biro Sensus Amerika Serikat, per 1 Januari 2015 jumlah penduduk dunia telah menembus angka 7,2 milyar jiwa (Republika, 2015). Dengan jumlah itu tentu saja ada banyak mulut untuk diberi makan dan minum agar dapat hidup dan produktif. Di luar itu, tentu saja manusia membutuhkan alat untuk menopang kebutuhan dan aktivitas mereka, misalnya kendaraan untuk pergi bekerja, pabrik untuk memproduksi barangbarang, dan seterusnya. Kebutuhan manusia di jaman serba canggih dewasa ini tidak hanya sebatas makan, minum, dan bekerja, tetapi juga kebutuhan menggunakan perangkat teknologi mutakhir seperti telepon seluler, laptop, komputer tablet, dan perangkat-perangkat canggih lainnya.

Terdapatempat kebutuhan pokok manusia di abad ke-21, yaitu pangan, air, energi, dan logam (Hiscock, 2012). Keempat kebutuhan pokok tersebut merupakan konsumsi dasar manusia. Semakin banyak jumlah penduduk dunia, semakin meningkat konsumsi mereka. Semakin meningkat konsumsi, semakin meningkat permintaannya. Semakin meningkat permintaan, semakin meningkat pula keinginan pemerintah suatu negara untuk mendapatkan sumber-sumber kebutuhan tersebut. Ketika peningkatan kebutuhan itu menjadi tak dapat dibendung, pemerintah akan menggunakan berbagai cara untuk mendapatkannya. Hal ini sangat berpotensi menjadi 'garis singgung' konflik antarnegara. Msalnya, kebutuhan akan energi. Kebutuhan Cina sekarang ini akan pasokan minyak sangat besar. Cina merupakan negara pengimpor minyak terbesar kedua di dunia setelah AS. Kebutuhan minyak Cina diperkirakan mencapai 10,7 juta barel per hari (U.S Energy Information Administration, 2014). Sebagai salah satu kekuatan dunia yang sedang bangkit, Cina membutuhkan suplai energi yang sangat besar untuk menggerakkan sektor industrinya. Salah satu implikasi dari kepentingan ini adalah konflik di Laut Cina Selatan di mana Cina terlihat sangat agresif untuk menguasai kawasan yang menyimpan cadangan minyak sebesar 11 milyar barel dan gas 190 triliun kaki kubik itu (U.S Energy Information Administration, 2014).

Contoh kedua adalah logam mulia. Jika dahulu para penjajah Eropa berperang untuk mendapatkan akses terhadap rempah-rempah dan emas, kini industrialisasi mendorong negara-negara mendapatkan akses terhadap logam-logam yang jauh lebih mulia daripada emas dan perak. Beberapa unsur tanah langka seperti scandium, yttrium, lantanum, dan cerium adalah sumberdaya alam masa depan yang saat ini menjadi unsur terpenting dari perangkatperangkat canggih seperti bahan baterai untuk mobil hibrida, i-Pad, Blackberry, ponsel cerdas, lensa kamera, memori komputer, bahkan sistem rudal terpandu (Hiscock, 2012: 3). Kepentingan ekonomi di balik produksi alatalat berteknologi tinggi akan membawa negaranegara maju ke dalam friksi-friksi yang akan terjadi di masa depan. Pola konflik antarnegara seperti ini sudah pernah terjadi. Pada tahun 2012, misalnya, AS, Jepang, dan 27 negara anggota Uni Eropa menuntut Cina ke World Trade Organization (WTO) karena membatasi pasokan logam langka. Cina menguasai 97 persen suplai logam langka dunia sehingga memiliki posisi tawar yang tinggi terhadap negara industri maju. Monopoli Cina justru memicu konflik dengan negara-negara maju yang kemudian ingin mencari sumber-sumber baru untuk mengamankan pasokan. Afrika dan sejumlah negara lainnya kemungkinan besar akan menjadi lahan perburuan logam langka di kemudian hari.

\section{Kesimpulan}

Memprediksi gambaran konflik dunia di masa depan tidak mudah, sama halnya dengan 
memprediksi bagaimana perdamaian dunia bisa terwujud. Secara keseluruhan, buku ini dapat dikatakan hanya tinggal obsesi. Buku ini berupaya merumuskan suatu teori baru tentang konflik internasional di abad ke-21, tetapi gagal dalam menyediakan bukti-bukti empiris untuk mendukungnya. Kontribusi teoritis yang diharapkan dapat memberikan paradigma baru dalam memahami masa depan politik dunia masih menyisakan tanda tanya besar. Kegagalan buku ini dalam memilah antara pergeseran kekuasaan (power shifting) dan demokratisasi berujung pada kemenduaan teori "benturan demokratisasi" dalam memprediksi konflik antarnegara di abad ke-21.

Pemilihan Arab Spring sebagai titik tolak perumusan teori "benturan demokratisasi" tidak ditindaklanjuti secara konsisten. Alihalih memprediksi apa yang bakal terjadi dengan negara-negara demokrasi baru dalam hubungannya dengan negara-negara demokrasi Barat, buku ini justru menyimpang dengan membahas kasus-kasus konflik antara emerging powers dan Barat mengenai tata kelola global. Alhasil, teori Harrison dan Mitchell cacat secara internal karena inkonsistensi dalam bangunan argumentasinya. Padahal, teori yang baik minimal mengandung dua syarat: sahih secara internal dan sahih secara eksternal. Untuk sahih secara internal, sebuah teori harus konsisten dalam segi logika berpikirnya. Sebagai contoh, jika ingin merumuskan teori tentang negara maju, maka negara maju harus menjadi variabel yang dijelaskan, bukan negara miskin. Sedangkan sahih secara eksternal maksudnya adalah bahwa sebuah teori harus cocok dengan fakta-fakta yang terjadi. Teori "benturan demokratisasi" tidak sahih secara internal karena tidak konsisten antara apa yang ingin dijelaskan dan logika apa yang mendasarinya. Walaupun berguna untuk memahami pola interaksi internasional kontemporer, teori ini tidak lebih daripada upaya mengafirmasi kecenderungan global dengan bangkitnya negara-negara non-Barat, atau meminjam istilah Fareed Zakaria (2008), "the rise of the rest." Bedanya, teori ini bernada pesimistis karena percaya bahwa masa depan politik internasional bernuansa konfliktual ketimbang kerjasama.

Terlepas dari itu semua, buku ini berhasil mengombinasikan berbagai pendekatan yang tampak saling berseberangan menjadi satu paradigma tunggal yang koheren. Berbeda dengan kebanyakan teoritisi yang cenderung mendasarkan diri pada satu paradigma tunggal, buku ini memakai metodologi campuran atau apayangkemudian dikenaldengan "pendekatan eklektis" (Sil and Katzenstein, 2010). Bangunan teoritis buku ini setidaknya menggabungkan tiga paradigma, yaitu paradigma konflik yang dipinjam dari Huntington, paradigma kemenangan demokrasi dari Fukuyama, dan paradigma pragmatismenya Mahbubani. Kombinasi berbagai pendekatan ini menarik sehingga menjadi kontribusi berharga bagi khasanah pemikiran dalam lingkup studi HI kontemporer. Sebagai gagasan yang berorientasi prediktif, dunia masih menanti apakah prediksi teori "benturan demokratisasi" yang dikemukakan dalam buku ini akan menemukan pembuktiannya, serupa dengan serangan teroris 11 September yang membuktikan tesis Huntington dan Arab Spring yang membuktikan tesis Fukuyama.

Kompleksitas hubungan internasional abad ke-21 tidak menghalangi kita untuk menerka-nerka seperti apa gambaran masa depan umat manusia. Bagaimanapun, konflik dan pertumpahan darah akan terus terjadi di tengah-tengah gelombang demokratisasi dan meningkatnya standar kehidupan masyarakat dunia. Skenario konflik di masa yang akan datang akan memiliki banyak bentuk. Tulisan ini memberikan sudut pandang yang berbeda dengan skenario yang ditawarkan buku ini. Tiga skenario konflik masa depan yang paling mungkin adalah perang asimetris antara negara melawan kelompok radikal, konflik antarnegara akibat keterbukaan informasi yang tak dapat 
dibendung, dan konflik antarnegara akibat perebutan sumberdaya alam yang semakin langka. Gambaran suram tentang masa depan umat manusia di abad ke-21 hendaknya menjadi bahan kajian dan refleksi mendalam bagi seluruh elemen masyarakat internasional untuk mencari strategi paling masuk akal untuk mengelola konflik-konflik mendatang dengan baik agar dunia menjadi lebih aman untuk ditinggali.

\section{Daftar Pustaka}

Betz, D. and T. Stevens. (2011). Cyberspace and The State: Toward A Strategy for Cyber-Power. London: Routledge \& IISS.

Bremmer, I. (2012). Every Nation for Itself: Winners and Losers in a G-Zero World. London: Penguin.

Bush, G.W. (2003). Bush makes historic speech aboard warship. (Online). (http://edition. cnn.com/2003/US/05/01/bush.transcript/, diakses 2 Juli 2015).

Cooper, A. and A. Alexandroff. (2010). Introduction. Dalam A. Cooper and A. Alexandroff (eds.), Rising States, Rising Institutions: Challenges for Global Governance. Washington D.C: Brookings Institution Press.

Diamond, L. (1997). Introduction: In Search of Consolidation. Dalam L. Diamond, et.al (eds.), Consolidating the Third Wave Democracies: Regional Challenges. Baltimore: John Hopkins University Press.

Diamond, L. (1997). The End of the Third Wave and the Global Future of Democracy. Political Science Series No. 45 (July).

Ferguson, Y. and R. Mansbach. (2004). Remapping Global Politics: History's Revenge and Future Shock. Cambridge: Cambridge University Press.

Friedman, G. (2009). The Next 100 Years: A Forecast for the $21^{\text {st }}$ Century. New York: Doubleday.

Garrett, N. and A. Piccini. (2012). Natural Resources and Conflict: A New Security Challenge for the European Union. Stockholm: SIPRI.
Huntington, S. (1991). Democracy's Third Wave. Journal of Democracy, Vol. 2, No. 2 (Spring), pp. 12-34.

Huntington, S. (1993). The Clash of Civilization? Foreign Affairs, Vol. 72, No. 3 (Summer), pp. 22-49.

Kahler, M. (2013). Rising Powers and Global Governance: Negotiating Change in A Resilient Status Quo. International Affairs, Vol. 89, No. 3, pp. 711-729.

Kliman, D. and R. Fontaine. (2012). Global Swing States: Brazil, India, Indonesia, Turkey and the Future of International Order. Washington, DC: Center for a New American Security and the German Marshall Fund of the United States.

Kupchan, C. (2012). No One's World: The West, the Rising Rest, and the Coming Global Turn. New York: Oxford University Press.

Lebow, R. (2010). Why Nations Fight: Past and Future Motives for War. Cambridge: Cambridge University Press.

Liveleak (2014). Snowden document revealed: ISIS caliphate working for America and Israel. (Online). (http://www.liveleak.com/ view?i=76b_1406255768, diakses 20 Juni 2015).

Mahbubani, K. (2011).Asia Hemisfer Baru Dunia: Pergeseran Kakuatan Global ke Timur yang Tak Terelakkan, terj. Th. Bambang Murtianto. Jakarta: Kompas Media Nusantara.

Mearsheimer, J.and S. Walt. (2013). Leaving theory behind: Why simplistic hypothesis testing is bad for International Relations. European Journal of International Relations, Vol. 19, No. 3, pp. 427-457.

Narlikar, A. (2006). Peculiar Chauvinism or Strategic Calculation? Explaining the Negotiating Strategy of A Rising India. International Affairs, Vol. 82, No. 1, pp. 59-76.

Nye, J. (2011). The Future of Power. New York: Public Affairs.

O'Neill, J. (2001). Building Better Global Economic BRICs. Global Economic Paper, No. 66 (November). 
Republika. (2015). Jumlah penduduk dunia terus meningkat. (Online). (http://www.republika. co.id/berita/internasional/global/15/01/01/ nhgy2a-jumlah-penduduk-dunia-terusmeningkat, diakses 2 Juli 2015).

Rosyidin, M. (2013). Politik Luar Negeri dalam Suasana Dilema: Politik Keseimbangan India terhadap BRICS dan Amerika Serikat, tesis MA, tidak dipublikasikan, Universitas Gadjah Mada.

Schmidt, E. and J. Cohen. (2013). The New Digital Age: Cakrawala Baru Negara, Bisnis, dan Hidup Kita, terj. Selviya Hanna. Jakarta: Kepustakaan Populer Gramedia.

Sil, R. and P. Katzenstein. (2010). Analytic Eclecticism in the Study of World Politics: Reconfiguring Problems and Mechanisms across Research Traditions. Perspectives on Politics, Vol. 8, No. 1 (June), pp. 411-431.

Slantchev, B. (2014). Crisis in Ukraine, Part 2: The Cold War Syndrome. (Online). (http:// slantchev.ucsd.edu/comments/2014-4-coldwar-syndrome.html, diakses 14 Oktober 2014).

U.S Energy Information Administration. (2014). China. (Online). (http://www.eia. gov/countries/cab.cfm?fips=ch, diakses 15 Oktober 2014).

Xiaoyu, P. (2012). Socialisation as a Two-way Process: Emerging Powers and the Diffusion of International Norms. The Chinese Journal of International Politics, Vol. 5, No. 4(Winter), pp. 341-367.

Zakaria, F. (2008). The Post-American World. New York: W.W Norton. 